\title{
Cultural Considerations in the Division of Labor
}

\author{
Lyn Craig* and Ruth Habgood
}

*lyn.craig@unimelb.edu.au ORCID: 0000-0001-9723-7255

Post peer-reviewed, pre copyedited version of chapter published as Craig, Lyn and Habgood, Ruth 'Cultural Considerations in the Division of Labor' in The Cambridge Handbook of the Global Work-Family Interface. Editors: Shockley, Kristen, Shen, Winny, Johnson, Ryan C. First: 646-660. Cambridge University Press, Cambridge 2018 ISBN 9781108245074

When we think about work and labor, the spotlight is usually on paid employment. But also essential is non-market, or unpaid, work: housework, home maintenance, and looking after children and elders as well as family members who are sick or are living with a disability. These latter activities are not rest or leisure. They are not hobbies. They are work; specifically, what economists call household production (Kalenkoski \& Foster, 2015). They require time and effort, and they have productive outcomes. How market and non-market work is divided by gender is a critical social issue. This chapter examines what we have discovered about the gender division of paid and unpaid work over the past few decades and how individual characteristics, family and workplace arrangements, and national contexts influence these patterns.

\section{Paid Work and Unpaid Work are Both Essential}

Societies and economies rely on both market and non-market work. Both require time and effort, and both are productive. That is to say, they have economically valuable outcomes. Following industrialization, paid and unpaid labor became gendered and spatially differentiated. Men worked for money outside the home; women's domestic production and mothering roles largely remained in the home. A consequence of this shift was that 'work' came to be seen as only those activities which resulted in the production of goods and services that have monetary value. As non-market work was not exchanged for money, it was no longer conceptualized as economically productive and no longer widely recognized as being “real” work (Folbre, 2001).

As a consequence, over time, the value of domestic and caring work to household and to national well-being has become obscured. This is despite the crucial role that non-market work plays in underpinning the economy and perpetuating the society. Domestic labor and family care are not simply family or personal matters. They have benefits that extend to the whole of society because to function successfully, societies depend not only on the market economy but also on an adequate supply of unpaid work and family care (Fineman, 2004). This work is essential if children are to be born and reared into independent adults, daily family needs met, and disabled, infirm, or elderly relatives cared for. Consequently, both governments and the market are profoundly dependent on the unpaid domestic labor, care, and human capital inputs that individuals and families provide. 
Although overlooked in conventional economic accounting, the unpaid economy is very large. Cross-national estimates of what it would cost to pay replacement wages for unpaid work range between 40 and 70 percent of GDP (OECD, 2016). Depending on the wage attributed, the replacement value of family care in the United States has been estimated at \$140 billion, \$257 billion, or \$389 billion a year, and in the United Kingdom estimates have been put at $£ 87$ billion a year (Buckner \& Yeandle, 2007).

Although costing unpaid work and care in monetary terms is very important, this approach on its own does not go far enough to understand the division of labor and its consequences. The social, economic, and personal significance of domestic work and care responsibilities is not only what they are worth in financial terms, but also the time they involve and the impacts that undertaking this work has on other activities and outcomes. Knowing how much time is spent in domestic work and caring activities is crucially important in understanding contemporary equality and barriers to it. In modern money-based economies, there are strong financial incentives to avoid doing unpaid domestic or care work, or to have others perform it on your behalf. Growing rewards in the labor market raises the opportunity cost of withdrawing from the workforce to care for family members; fewer people are able to do it, and as a result, both the supply of unpaid care and the well-being and financial security of those who still provide it are in jeopardy.

Raising children, for example, can be viewed as public-goods provision which, if not compensated, allows citizens who do not provide it to free-ride on the efforts of those who do (Folbre, 1994a). Public goods are those that cannot be supplied to any one person without benefiting others, and the use of which by any one person does not preclude their use by others (Caporaso \& Levinde, 1992). An example is lighthouses, which protect all ships from harm, including those that do not contribute to their cost (Bittman \& Pixley, 1997). Children similarly generate diffuse benefits. Child-raising involves very substantial private investment in human capital and the cumulative cost to parents in terms of time, money, and energy from birth to adulthood is huge (Folbre, 1994b). The long-term economic return on this investment is also substantial, but it largely flows not to the parents who rear them, but to others, including the government, employers, and the whole community in the form of productive citizens, workers, and community members (Chesnais, 1998; Folbre, 1994a, 1994b).

The care penalty is reinforced in many modern economies by public policy shifts based on the expectation that all adults will be workers regardless of gender and notwithstanding care responsibilities (Lewis, 2006). For example, people who withdraw from paid work to care for children or others may not only lose income in the short term but also suffer cumulative material disadvantage over the lifetime through lost access to promotion opportunities, retirement income, and health funds (Sigle-Rushton \& Waldfogel, 2007). This means that the costs of care over the lifetime include being at risk of poverty in old age. In such circumstances, providing care is a major life-course risk (Lewis, 2006). Conversely, if carers do not withdraw from the workforce, they may be subject to overwork and time strain, which can adversely affect their health and well-being (Strazdins \& Loughrey, 2007). Time scarcity is at the center of significant concern about the quality of contemporary life. The feeling of being rushed, harried, and having too much to do is widely attributed to the ongoing challenge of balancing work and family demands and the division of paid and unpaid labor (Edwards \& Wajcman, 2005). It is, therefore, important to make time spent in unpaid work and care visible alongside paid work and to show how much is done, who does it, and the consequences for those who do it. 


\section{The Division of Labor: What Do We Know?}

To remedy the invisibility of unpaid work, to inform policy, and to calculate its worth to national economies, the United Nations advocates using Time Use Surveys to calculate the quantum of non-market work and compile Satellite Accounts to supplement calculations of GDP. Time diaries involve data on the time people spend in all activities throughout the day, including sometimes data from multiple household members. This information can be used to identify the distribution of paid and unpaid work within households. Time use surveys have supported the emergence of a much clearer and more nuanced understanding of the familypaid work division of labor, its variability, its gendered nature, and its social and economic consequences (for more information on Time Use Surveys in the work-family interface, see Chapter X). Satellite Accounts refer to measures of the size of economic sectors that are not defined as industries in national accounts (e.g., unpaid household work, the environment), which enables attention to be focused on these aspects of economic and social life that are often not included in national accounts of GDP.

Cross-national time use studies show that time spent in unpaid work and care amount to many hours per day and also that gender differences in time allocated to paid and unpaid work is universal (Hook, 2006). For example, a six country study compared average minutes per day spent in domestic work (i.e., cooking, cleaning, clothes care, shopping, and childcare) by women and men in Canada (275 vs 140), the United Kingdom (287 vs 146), the United States (281 vs 146), Denmark (232 vs 132), Finland (239 vs 137), and Sweden (288 vs 172) (Gershuny \& Sullivan, 2003). The study also compared women's and men's average minutes per day in paid work time in Canada (331 vs 374), the United Kingdom (316 vs 373), the United States (312 vs 393), Denmark (283 vs 364), Finland (271 vs 343), and Sweden (274 vs 354) (Gershuny \& Sullivan, 2003). Thus, although national averages varied, in all cases men's average paid work time was higher than women's, and women average unpaid work time was higher than men's. Recent data from the Organization for Economic Co-operation and Development (OECD) shows this pattern is still ubiquitous and occurs in countries as diverse as Turkey, Japan, and Korea (where men do about a fifth of the unpaid work that women do) and New Zealand and Poland (where men do about half the unpaid work that women do) (OECD, 2016).

As women entered the workforce in increasing numbers and gained income and bargaining power, it was expected that the gender division of both paid and unpaid work would become more equal (Bergmann, 1986). There has indeed been some gender convergence in market and family work over time, although the pace is slow in many countries (Altintas \& Sullivan, 2016). Moreover, although men have increased their domestic participation over recent years, it has not been at the same rate as women have taken up market work. The convergence was largely because as more women entered the paid labor force they did less housework than in times past, lowering the overall quantum rather than directly trading-off with men (Bianchi, Milkie, Sayer, \& Robinson, 2000). Even when both male and female household partners have full-time jobs, the woman still does significantly more housework than the man (Bianchi \& Milkie, 2010). Indeed a recent comprehensive review of the research suggests that no matter what factors are taken into account, gender emerges as the strongest predictor of how labor is divided (Shockley \& Shen, 2016).

Gender differences do vary by family structure, education, workforce participation status, and over the life course. However, generally speaking, at each life stage, more of men's labor is paid than women's. Men continue to specialize in paid work while women's labor includes a higher proportion of productive work, specifically housework, childcare, and 
elder care, that is unpaid (Lewis, 2009). This is true to an even greater extent when women are partnered compared to single and to the greatest extent of all when they are parents of young children. The transition to parenthood is the life course event that most clearly impacts the gender division of labor within families (Baxter, Hewitt, \& Haynes, 2008). This is mainly because, on becoming fathers, men do not reduce their paid work time, but on becoming mothers, women are much more likely to cut back on paid work and to do more care (Craig \& Bittman, 2008). It is still rare that fathers have the primary responsibility for child care and women are still much more likely than men to move in and out of the workforce, or limit their paid work hours to care for young children or for other dependents (Baxter \& Gray, 2008). However, there are exceptions, and some have argued that it is not "gender per se but gendered divisions of care giving labor, especially mothers' withdrawals and reductions in employment, that are the primary cause of continued male-female disparities in wages and occupational attainment” (Gornick \& Meyers, 2007, p. 11). If men have the primary responsibility for care, they too suffer disadvantage in the workplace, and conversely, if women avoid it, they can compete more equally with men in the workplace (Folbre, 2007).

At the same time there is evidence that both mothers and fathers are spending more time with children than in times past, despite families becoming smaller. This is also despite mothers doing more paid work, and on average fathers not limiting theirs, which suggests that more overall time is being committed both to work and to family. The increase in childcare time is true for both genders and in most industrialized countries (Cooke \& Baxter, 2010). It has been suggested that the trend is driven by burgeoning social expectations regarding what constitutes adequate parenting (Coltrane, 2007). Some argue this is a middle class phenomenon (Lareau, 2003). Educated fathers spend more time with children than lesseducated fathers, and more highly educated women seem reluctant to trade off time caring for their children either with their partners, or with paid employment despite their improved market opportunities (England \& Srivastava, 2013). However, single mothers also prioritize childcare, despite arguably facing a starker choice between earning income and providing care for their children (Craig \& Mullan, 2012). Over the life course other forms of care, including for sick or disabled relatives or for elder family members, are also more likely to be done by women than by men (Lewis, 2009).

\section{Influences on the Division of Labor}

Although broad patterns confirm the persistence of unequal gender division of care and other unpaid work, some factors have been identified as mitigating it. The bulk of the literature has focused on three possible levers: time availability, relative resources, and gender ideology (see Bianchi \& Milkie, 2010 for an overview). These factors generate predictions about the gender division of labor within couples. For example, it is expected that the spouse with higher earning capacity (captured through education or earnings) will do the most market work, and the spouse who does the most market work will do the least nonmarket work. Those who work longer market hours will have less time for unpaid work than those who work short market hours. Couples with more conservative gender ideology are expected to adopt more traditional divisions of paid and unpaid work than those with more progressive ideology. Empirical research suggests that these explanations are partial at best, and none are sufficient to wholly explain the gender division of labor (see Lachance-Grzela \& Bouchard, 2010 for an overview). This may be because they are inextricably linked, and gender is fundamental to all. Labor markets yield unequal earnings for men and women, which reflects and influences couples' decisions on who should commit more time to market 
work, affect mothers' and fathers' relative resources and household bargaining power, and reinforce attitudes about appropriate gender roles.

In the pursuit of factors that might support work-family reconciliation, a series of Australian studies considered the effects of work conditions and arrangements on the gender division of labor and subjective time pressure in two parent family households. Predictors examined included part-time work, nonstandard work schedules, working at home and flexible hours, self-employment, non-parental childcare, and domestic outsourcing. The series of studies asked, in essence: what difference do family work sharing choices, outsourcing, and personal working conditions make to 1) household total work, 2) the gender division of labor, and 3) time stress? These questions are addressed in the sections below.

\section{Non-parental childcare}

When non-parental childcare was utilized, the gender division of labor was slightly more equal. Non-parental childcare can include formal day care, nannies, non-formal arrangements with family or friends, or some mixture of these. Mothers who used formal non-parental care did more paid work than mothers who did not. They did less domestic work than other mothers, but the reduction in the amount of childcare was much lower. This is probably because activities like bathing, feeding, and supervising homework are shifted to the evening after parents and children get home. Also, with formal care arrangements, mothers' time stress was higher, likely due to the added pressure of meeting deadlines, particularly for delivering children to day care before work and for picking them up at the end of the day (Craig \& Powell, 2013).

Informal non-parental care was not associated with longer parental work hours or higher time pressure, perhaps because it is more flexible and usually provided by family. Increasing numbers of grandparents now provide regular care while parents work. Incidence echoes the patterns found among parents, namely that it is disproportionately done by women. Results suggest that as more young women are in paid work, some care is transferring from younger to older women, thus spreading care across the life course rather than being distributed more equally with men. Many grandmothers are giving up or cutting back on paid work to allow their own daughters to work. Regular care provision is associated with less leisure for grandparents of both genders and doubles the likelihood of grandmothers reporting high subjective time pressure (Craig \& Jenkins, 2015).

\section{Domestic outsourcing}

Studies into whether domestic outsourcing (i.e., paid household help) improves the gender division of labor have found mixed results, with some suggesting that it reduces domestic time as much for men as for women (see Craig \& Baxter, 2016 for an overview). Recent research using longitudinal data suggests, however, that for those women who can afford domestic help it can somewhat reduce housework time, narrow gender gaps, and lower women’s subjective time pressure (Craig, Perales, Vidal Torre, \& Baxter, 2016).

\section{Work conditions/arrangements}

Parents who work nonstandard hours (i.e., evenings, nights, or weekends) spend significantly longer in paid work and less time on housework and childcare than those who work standard hours. Nonstandard hours had mixed effects on the gender division of labor. Mothers' nonstandard hours have minor positive effects on the gender division of labor 
because fathers perform more childcare while the mother is absent. Conversely, when fathers work nonstandard hours, mothers do more housework and routine childcare, so the gendered division of labor intensifies (Craig \& Powell, 2011). Fathers' nonstandard hours are also associated with working longer hours and doing less housework and care than fathers who work standard hours. These fathers also report more time stress, as do their partners (Craig \& Brown, 2016).

Self-employment and working from home potentially offer parents the kind of flexibility they need to better manage work and family demands. Although these arrangements seem to facilitate some rescheduling, research suggests that they do not appear to involve gender redistribution of paid and unpaid work. They are associated with more variation in women's time than in men's, particularly in relation to the length of market work hours. As such, these arrangements are more likely to reinforce, rather than challenge, household gender divisions because they are associated with women doing more housework and care or result in men doing more paid and less unpaid work (Craig, Powell, \& Cortis, 2012; Powell \& Craig, 2015).

Despite the potential of the aforementioned arrangements to facilitate more equal sharing of paid and unpaid work, results suggest that they do so only marginally or not at all. Also, although some of the strategies studied had slightly positive effects on the gender division of labor, none reduced women's subjective time stress or overall workload when both paid and unpaid work are taken into account. This was because they facilitated rescheduling their paid work and family responsibilities around each other, allowing one type of work to take over from another. This was particularly apparent with part-time female work hours, the strategy most commonly adopted by Australian parents trying to balance work and family demands. Women's part time work was associated with longer male paid work and less unpaid work, and the converse for women. Whether mothers worked full- or part-time, their total workloads were much the same. When they did less paid work, unpaid work took its place-although full-time work brought more subjective time stress (Craig \& Powell, 2012).

Taken as a whole, the answer this series of Australian studies gave to the question of what difference various work strategies or family-level arrangements make to the gender division of labor was "not much." The results suggest that family-level variation in work/care strategies and arrangements have little overall effect on workloads, and only slightly alleviate or actually reinforce the gender division of labor. However, Australia is a country in which collective measures (e.g., national paid parental leave and accessible, affordable childcare) to assist work-family balance are relatively sparse, and the outcomes noted above may be related to the absence of broader policy support.

\section{Cross-National Variation in the Division of Labor}

Most research on the gender division of labor highlights the role of individual beliefs, family resources, and household circumstances. It is recognized, however, that beyond individual and household micro-level factors, the demands of work and family and the options for meeting them are strongly influenced by macro-level factors, including workingtime systems and social policies (Gornick \& Meyers, 2009).

Cross-nationally, social policies can facilitate or hinder combining work and family, including exacerbating or ameliorating gender differences in workforce participation. National context can also affect intra-household decisions by "influencing the terms of 
bargaining, the benefits of specialization, and the ease or difficulty of adhering to gender norms” (Hook, 2006, p. 642). Importantly, national contexts affect how much care families directly carry out and how it is divided between men and women. Norms and attitudes matter too. For example, there are cultural differences in ideas about what children need and who should best provide it and related variation in both the accessibility of substitute care and whether parents wish to use it (Duncan \& Edwards, 2003). Although some countries provide extensive social supports, others regard family care as primarily a private responsibility. The institutional framework affects the gender division of labor, as the responsibility for nonmarket work usually reverts to women if no supports are provided (Lewis, 2009). Although the primary effect is on women's employment, cross-national differences in policies have also been found to predict men’s family involvement (Hook, 2006).

The strength and importance of macro-level factors in shaping the division of labor is revealed in variety across different national contexts and in the different pace of change that has occurred over time (Altintas \& Sullivan, 2016). Comparing time use surveys crossnationally across different policy environments can tell us not only what is happening, but also what change is possible. In other words, it can help to identify how to make changes. For example, one cross-national study of how paid and unpaid work time allocation varies with parenthood, found that the gender division of labor is more likely to be more equal in countries where there is a suite of policies assisting work-family reconciliation (e.g., paid parental leave, available and affordable childcare, and state-subsidized elder care), as is often the case in Nordic social democracies (Lewis, 2009). These measures make it easier to divide paid and unpaid labor more equally by gender than in countries in which there is little public institutional support to balance work and family, such as Southern Europe, Asia, or liberal Anglo countries. For example, in the United States and Australia, solutions to the gender division of labor are more individual and must be implemented in the face of higher overall workloads (Craig \& Mullan, 2010).

The interplay between policies and attitudes is iterative, complex, and multidirectional (Lewis, 2009). The normative ideal that young children need constant and sustained parental attention seems particularly strong in Anglo countries (Duncan \& Edwards, 2003). In Northern European countries (e.g., Finland, Sweden, Denmark), there is more public acknowledgment of the important contribution that care makes to society, and this is reflected in the greater public provision of elderly and childcare services, as examples. It is important to note, however, that such policies mean that a more gender-equal division of labor results from the state relieving households of much direct responsibility for care. Thus women can do less, but it is not necessarily the case that men do more (Craig \& Mullan, 2010). Also importantly, in these countries paid working hours are short by international standards, giving people more opportunity to do unpaid work with less career penalty than elsewhere. Reduced average full-time working hours for both men and women may be the most effective route to mitigating the gender division of labor.

Long working hours make it harder to divide paid and unpaid labor equally, and much more likely that both individuals and their families will feel time pressured. Levels of time stress are important measures of family welfare and of men and women's comparative wellbeing, which also vary with national context. Although long working hours are stressful for most people, including for single and coupled individuals, full-time work combined with care responsibilities is particularly demanding. Research suggests that mothers become time stressed at lower working hours than fathers, reflecting their greater non-market work burden. It is also the case that men's longer work hours are associated with higher time stress not only 
for the men themselves, but also for their partners (Craig \& Brown, 2016). Time stress is particularly high when children are young. In Australia, over $90 \%$ of mothers and $70 \%$ of fathers working full-time with children under five report being 'always' time stressed (Craig \& Mullan, 2009). Although stress levels reduce as children age, they remain high. This is in contrast with Finland, where the level of time stress for both mothers and fathers is much lower, likely because lower average full-time work hours for both genders gives everyone more flexibility to balance work and family (Craig, Brown, Strazdins, \& Jun, forthcoming).

However, time quality also impacts subjective time stress. For example, compared to inadequate good quality leisure, adequate quality leisure predicts better physical and mental health (Strazdins \& Loughrey, 2007). Gender differences in leisure are related to the gendered division of labor and also affect the relative welfare of men and women. Leisure equality is an important supplementary indicator to economic equality. It offers a perspective on men and women's comparative well-being additional to that shown by gender gaps in market and non-market work (Shaw, 2008). As conventionally measured, average leisure time is higher in some countries than in others, but within most countries men and women have similar amounts. However, when the quality of leisure is considered, and specific demographic groups investigated, there is considerable gender divergence. Studies in the United States, for example, find that mothers have less leisure time than fathers, especially when both parents work or when children are young (Sayer, England, Bittman, \& Bianchi, 2009). Mothers' personal leisure quality is lower than fathers' because it is less often childfree (Mattingly \& Bianchi, 2003). As a result, mothers' free time does not reduce subjective time stress to the same extent as it does fathers (Craig \& Brown, 2016). Overall leisure time is higher for parents in European countries than parents in non-European countries, but even in Europe the quantity and quality of leisure time, particularly the proportion that is childfree, still favors fathers more than mothers (Craig \& Mullan, 2013).

Across a variety of areas and contexts, the studies above demonstrate the variability in the gender division of labor on a national rather than an individual scale and show the impact of policies supporting states sharing responsibility for care relative to contexts where this does not occur. National context and policy settings clearly make a difference.

\section{National Policy Effects within Countries}

Although comparative time use studies demonstrate that an unequal gender division of labor is ubiquitous, they also demonstrate its malleability. This work has uncovered considerable variation in how families manage paid and unpaid work in their lives, with varying household characteristics and employment conditions. These studies demonstrate the powerful role that government policies play in producing the gendered work and family care patterns that we observe. This is not only apparent in cross-national comparisons, but also over time within countries.

As an example, Australian research has demonstrated that substantial changes to work-family balance are possible within relatively short time frames. In the period from 1997-2006, Australia experienced booming economic conditions and increasing higher education levels, especially for women. These conditions could be expected to promote greater female workforce participation. However, a series of policy decisions were made by a socially conservative government that resulted in more gendered work-family arrangements over the time period (Craig, Mullan, \& Blaxland, 2010). Specifically, there were tax disincentives for partnered mothers to work, limited paid parental leave, and insufficient affordable childcare places, measures underpinned by high rhetorical support from the 
government for families with a full-time employed father and a part-time employed mother. The rhetorical support took the form of frequent policy and political speeches and media discussion of the topic. As a result, by 2006 there was lower average maternal market work and a higher proportion of families with young children conformed to the one-and-a-half earner family form than in 1997 (Craig \& Mullan, 2009). There was increased total household work, increased gender specialization in paid work and caring labor, and much higher subjective time pressure, especially for fathers and the relatively few mothers who were employed full-time (Craig et al., 2010).

Although the Australian case involved turning back the clock for gender parity, it does suggest that policies and government backing can influence changes in the gender division of labor relatively quickly. Research investigating the impacts of policy change in the Netherlands, for example, investigated the effects on mothers' workforce participation of three related policy developments: the introduction of part-time parental leave, strong growth in part-time jobs, and improvements in the labour market position of part-time workers (Begall \& Grunow, 2015). The study found that first-time Dutch mothers were significantly less likely to exit the labor force or reduce their hours when they had access to these measures than when they did not. The effect of family policies on men's labor market outcomes were examined in a large study of 28 European countries (Bünning \& PollmannSchult, 2015). This study found that fathers do less paid work than childless men if they live in countries that offer generous family allowances or well paid, non-transferable parental leave for fathers and short parental leave for mothers. However, there were educational differences in these results; specifically, for highly educated fathers, short maternal leaves were associated with shorter working hours, but for less educated fathers, reduced working hours were associated with generous family allowances and father friendly parental leave schemes (Bünning \& Pollmann-Schult, 2015).

\section{Implications and Future Directions}

Linking policies and outcomes in the ways described above is highly dependent on good quality data being available (Lohmann \& Zagel, 2015). Time use studies are particularly useful because they capture non-market work on the same metric as paid work. They can give more accurate and comprehensive measures of national productivity and its division by gender than economic data alone. On a micro-level they can show links between partners. They thus not only put the spotlight on undervalued and unnoticed activities, but can show how market and non-market work is divided within and across nations and within and across families.

In the future, the important contribution time use studies make to understanding the gender division of labor can be maintained and extended if national statistical agencies conduct them. This is an ongoing challenge, as high quality data collection is expensive. As more countries (e.g., Inner Mongolia, China) collect time use data for the first time, others (e.g., Australia) have cancelled planned collections due to budgetary reasons. It is also necessary to ensure survey design is similar enough to be harmonized for international comparison, through projects such as the Harmonized European Time Use Study (HETUS) and the Multinational Time Use Study (MTUS). Also important to future knowledge is to examine time patterns over the life course. In the absence of panel studies collecting time use data, high quality repeated cross-sectional collection from multiple countries can allow timeseries analyses investigating cross-national trends over time for different age cohorts. 
This work is necessary because the consequences of ignoring or devaluing socially necessary unpaid work and care are substantial both for those who do this work and for societies as a whole. Appropriately valuing and including unpaid work and care in political and policy decision making is crucial to avoid inequity. Being disproportionately responsible for non-market work in a monetized economy that values little else has negative outcomes. This can only be avoided if it is shared more equally. To ensure this, unpaid work must be systematically measured and counted alongside other decision-making metrics. National time use collections need to be institutionalized and compulsory as for other social and economic data. But collecting information, although necessary, is not sufficient. We also need politicians and policy makers to want the evidence and to want to use it, not only to inform policy but to also systematically evaluate its effectiveness over time. Ongoing cross-national studies are needed show how things can be done differently and to support effective change.

Systematic assessment of gender impact is required. In its absence, gender neutral policy making becomes male worker centric, a source of gender inequality and disadvantage and family unfriendly outcomes. For example, in many countries contributory retirement incomes assume traditional male employment patterns (i.e., full-time over the working lifetime) that do not include caring responsibilities. Women avoiding care responsibilities could work to achieve individual gender equality, but this is not a socially sustainable solution. Asia and Southern Europe, for example, have very low fertility rates and rapidly aging populations. They also have particularly wide gender divisions of labor. Many scholars connect the two, effectively arguing that gender inequity in paid and unpaid work has caused a baby strike (de Laat \& Sevilla-Sanz, 2011; Hobson, Olah, \& Morrissens, 2006; McDonald, 2006).

\section{Conclusion}

Comprehensive work-family supports are needed as part of the basic social infrastructure to support the provision of socially necessary non-market work. The need to be available to care or be the recipient of care is life long and a fundamental social requirement. Lack of formal supports devalue non-market work and mean women remain the default providers. It also denies care to higher need and less well connected individuals. Care and unpaid work, and how it is divided by gender, needs to be as central to public debate as it is central to our lives. Unpaid work and care undergird the economy. It is vital and productive activity. It should count. Those who do it should count. If the future is to involve employment on equal terms for both men and for women then the division of unpaid work and care also has to be fair and sustainable. 


\section{References}

Altintas, E., \& Sullivan, O. (2016). Fifty years of change updated: Cross-national gender convergence in housework. Demographic Research, 35(16), 455-470.

Baxter, J., \& Gray, M. (2008). Work and family responsibilities through life. Melbourne: Australian Institute of Family Studies.

Baxter, J., Hewitt, B., \& Haynes, M. (2008). Life Course Transitions and Housework: Marriage, Parenthood, and Time on Housework. Journal of Marriage and Family, 70(2), 259-272.

Begall, K., \& Grunow, D. (2015). Labour Force Transitions around First Childbirth in the Netherlands. European Sociological Review, 31(6), 697-712.

Bergmann, B. (1986). The Economic Emergence of Women. New York: Basic Books, Inc.

Bianchi, S., \& Milkie, M. (2010). Work and Family Research in the First Decade of the 21st Century. Journal of Marriage and Family, 72(3 ), 705-725. doi: 10.1111/j.17413737.2010.00726.x

Bianchi, S., Milkie, M., Sayer, L., \& Robinson, J. (2000). Is anyone doing the housework? Trends in the gender division of household labor. Social Forces, 79(1), 191-228. doi: 10.1093/sf/79.1.191

Bittman, M., \& Pixley, J. (1997). The Double Life of the Family. St. Leonards: Allen and Unwin.

Buckner, L., \& Yeandle, S. (2007). Valuing Carers - calculating the value of unpaid care: Carers UK, University of Leeds.

Bünning, M., \& Pollmann-Schult, M. (2015). Family policies and fathers’ working hours: cross-national differences in the paternal labour supply. Work, Employment \& Society, 30(2), 256-274.

Caporaso, J. A., \& Levinde, D. P. (1992). Theories of Political Economy. Cambridge: Cambridge University Press.

Chesnais, J.-C. (1998). Below-Replacement Fertility in the European Union (EU-15): Facts and Policies, 1960-1997. Review of Population and Social Policy, 7, 83-101.

Coltrane, S. (2007). Fatherhood, Gender and Work-Family Policies. Paper presented at the Real Utopias, The Havens Center, University of Wisconsin-Madison

Cooke, L. P., \& Baxter, J. (2010). 'Families' in International Context: Comparing Institutional Effects across Western Societies. Journal of Marriage and Family, 72, 516-536.

Craig, L., \& Baxter, J. (2016). Domestic outsourcing, housework shares and subjective time pressure: gender differences in the correlates of hiring help. Social Indicators Research, 125(1), 271-288. doi: 10.1007/s11205-014-083-1 
Craig, L., \& Bittman, M. (2008). The Effect of Children on Adults' Time-Use: An analysis of the incremental time costs of children in Australia. Feminist Economics, 14(2), 57-85. doi: 10.1080/13545700701880999

Craig, L., \& Brown, J. ( 2016). Feeling rushed: gendered time quality, work hours, work schedules and spousal crossover. Journal of Marriage and Family. doi: online first 10.1111/jomf.12320

Craig, L., Brown, J., Strazdins, L., \& Jun, J. (forthcoming). Gendered time symmetry and subjective time pressure in Australia, Finland and Korea In R. Connelly \& E. Kongar (Eds.), Gender and Time Use in a Global Context. USA: Palgrave MacMillan.

Craig, L., \& Jenkins, B. (2015). Grandparents' childcare in Australia: Gender differences in the correlates and outcomes of providing regular grandparent care while parents work. Community, Work \& Family. doi: 10.1080/13668803.2015.1027176

Craig, L., \& Mullan, K. (2009). The Policeman and the Part-time Sales Assistant: Household labour supply, family time and subjective time pressure in Australia 1997-2006. Journal of Comparative Family Studies, 40(4), 545-560.

Craig, L., \& Mullan, K. (2010). Parenthood, gender and work-family time in USA, Australia, Italy, France and Denmark Journal of Marriage and Family, 72(5), 1344-1361.

Craig, L., \& Mullan, K. (2012). Lone and Couple Mothers' Childcare Time Within Context in Four Countries. European Sociological Review, 28 (4), 512 - 526. doi: 10.1093/esr/jcr013

Craig, L., \& Mullan, K. (2013). Parental leisure time: a gender comparison in five countries. Social Politics: International Studies in Gender, State and Society, 20(3), 329-357. doi: $10.1093 / \mathrm{sp} / \mathrm{jxt} 002$

Craig, L., Mullan, K., \& Blaxland, M. (2010). Parenthood, Policy and Work-Family Time in Australia 1992-2006. Work, Employment and Society, 24(1), 1-19. doi: $10.1177 / 0950017012437006$

Craig, L., Perales, P., Vidal Torre, S., \& Baxter, J. (2016). Domestic outsourcing, housework and subjective time pressure: New insights from longitudinal data. Journal of Marriage and Family doi: online first 10.1111/jomf.12321

Craig, L., \& Powell, A. (2011). Nonstandard work schedules, work-family balance and the gendered division of childcare. Work, Employment and Society, 25(2), 274-291. doi: 10.1177/0950017011398894

Craig, L., \& Powell, A. (2012). Dual-earner parents' work-family time: the effects of atypical work patterns and formal non-parental care. Journal of Population Research, 29 (3), 229-247. doi: 10.1007/s12546-012-9086-5

Craig, L., \& Powell, A. (2013). Non-parental childcare, time pressure and the gendered division of paid work, domestic work and parental childcare. Community, Work and Family, 16(1), 100-119. doi: 10.1080/13668803.2012.722013 
Craig, L., Powell, A., \& Cortis, N. (2012). Self-employment, work-family time and the gender division of labour Work, Employment and Society, 26(5), 716. doi: $10.1177 / 0950017012451642$

de Laat, J., \& Sevilla-Sanz, A. (2011). The Fertility and Women's Labor Force Participation puzzle in OECD Countries: The Role of Men's Home Production. Feminist Economics, 7(2), 87-119.

Duncan, S., \& Edwards, R. (2003). State Welfare Regimes, Mothers' Agencies and Gendered Moral Rationalities. In K. Kollind \& A. Peterson (Eds.), Thoughts on Family, Gender, Generation and Class. A Festschrift to Ulla Bjornberg (pp. 22-40). Goteberg: Sociology Institute, Goteberg University.

Edwards, P., \& Wajcman, J. (2005). The Politics of Working Life: Oxford University Press.

England, P., \& Srivastava, A. (2013). Educational differences in U.S. parents' time spent in child care: the role of culture and cross-spouse influence. Social Science Research.

Fineman, M. (2004). The Autonomy Myth: A Theory of Dependency. New York: The New Press.

Folbre, N. (1994a). Children as Public Goods. The American Economic Review, 84(1552), 86-90.

Folbre, N. (1994b). Who Pays For The Kids? Gender and the structures of constraint. London and New York: Routledge.

Folbre, N. (2001). The Invisible Heart: economics and family values. New York: The New Press.

Gershuny, J., \& Sullivan, O. (2003). Time Use, Gender and Public Policy Regimes. Social Politics, 10(2), 205-228.

Gornick, J., \& Meyers, M. (2007). Further Thoughts. In E. O. Wright (Ed.), Real Utopias: Institutions for Gender Egalitarianism: Creating the Conditions for Egalitarian Dual Earner / Dual Caregiver Families. Madison: University of Wisconsin-Madison.

Gornick, J., \& Meyers, M. (Eds.). (2009). Gender Equality: Transforming Family Divisions of Labor (Vol. IV Real Utopias Project) London: Verso.

Hobson, B., Olah, L., \& Morrissens, A. (2006). The Positive Turn or Birth-strikes? Sites of Resistance to Residual male Breadwinner Societies and to Welfare State Restructuring. Paper presented at the RC19 Meetings of the ISA Sept 2-5, Paris.

Hook, J. (2006). Care in context: Men's unpaid work in 20 countries, 1965-2003. American Sociological Review, 71(4), 639-660.

Kalenkoski, C., \& Foster, G. (2015). The Economics of Multitasking. USA: Palgrave MacMillan.

Lachance-Grzela, M., \& Bouchard, G. (2010). Why do women do the lion's share of housework? A decade of research. Sex Roles, 63, 767-780. 
Lareau, A. (2003). Unequal Childhoods: Class, Race, and Family Life. Berkeley, CA: University of California Press.

Lewis, J. (2006). Employment and care: The policy problem, gender equality and the issue of choice. Journal of Comparative Policy Analysis: Research and Practice, 8(2), 103 114.

Lewis, J. (2009). Work-Family Balance, Gender and Policy. Cheltenham, UK, Northhampton, MA, USA: Edward Elgar.

Lohmann, H., \& Zagel, H. (2015). Family policy in comparative perspective: The concepts and measurement of familization and defamilization. Journal of European Social Policy, 28(1), 48-65.

Mattingly, M., \& Bianchi, S. (2003). Gender differences in the quantity and quality of free time: The U.S. experience. Social Forces, 81, 999-1030. doi: 10.1353/sof.2003.0036

McDonald, P. (2006). Low Fertility and the State: The Efficacy of Policy. Population and Development Review, 32(3), 485-510.

OECD. (2016). Paid and Unpaid Work. Organisation for Economic Co-operation and Development http://www.oecd.org/gender/data/timespentinunpaidpaidandtotalworkbysex.htm.

Powell, A., \& Craig, L. (2015). Gender differences in working at home and time use patterns: evidence from Australia. Work, Employment and Society, 29(4), 571-589. doi: $10.1177 / 0950017014568140$

Sayer, L., England, P., Bittman, M., \& Bianchi, S. (2009). How long is the second (plus first) shift? Gender differences in paid, unpaid, and total work time in Australia and the United States. Journal of Comparative Family Studies, 40, 523-544.

Shaw, S. (2008). Family Leisure and Changing Ideologies of Parenthood. Sociology Compass, 2(2), 688-703.

Shockley, K., \& Shen, W. (2016). Couple dynamics: Division of labor. In T. Allen \& L. Eby (Eds.), Oxford Handbook of Work and Family. Oxford: Oxford University Press.

Sigle-Rushton, W., \& Waldfogel, J. (2007). Motherhood and Women’s Earnings in AngloAmerican, Continental European, and Nordic Countries. Feminist Economics, 13(2), $55-91$.

Strazdins, L., \& Loughrey, B. (2007). Too busy: Why time is a health and environmental problem. NSW Public Health Bulletin, 18(11-12), 219-221. 


\section{University Library}

\section{- M M I N E R VA A gateway to Melbourne's research publications}

Minerva Access is the Institutional Repository of The University of Melbourne

Author/s:

Craig, L;Habgood, $\mathrm{R}$

Title:

Cultural Considerations in the Division of Labor

Date:

2018

Citation:

Craig, L. \& Habgood, R. (2018). Cultural Considerations in the Division of Labor. Shockley, K (Ed.). Shen, W (Ed.). Johnson, RC (Ed.). The Cambridge Handbook of the Global WorkFamily Interface, (First), pp.646-660. Cambridge University Press.

Persistent Link:

http://hdl.handle.net/11343/251910 